\title{
Antihyperglycemic and hypolipidemic effects of a, $\beta$-amyrin, a triterpenoid mixture from Protium heptaphyllum in mice
}

\author{
Flávia Almeida Santos ${ }^{1 *}$, Julyanne Torres Frota ${ }^{1}$, Bruno Rodrigues Arruda', Tiago Sousa de Melo², \\ Armenio André de Carvalho Almeida da Silva ${ }^{3}$, Gerly Anne de Castro Brito ${ }^{4}$, Mariana Helena Chaves ${ }^{3}$ \\ and Vietla Satyanarayana Rao ${ }^{1}$
}

\begin{abstract}
Background: Pentacyclic triterpenes in general exert beneficial effects in metabolic disorders. This study investigated the effects of $\alpha, \beta$-amyrin, a pentacyclic triterpene mixture from the resin of Protium heptaphyllum on blood sugar level and lipid profile in normal and streptozotocin (STZ)-induced diabetic mice, and in mice fed on a high-fat diet (HFD).

Findings: Mice treated with a, $\beta$-amyrin (10, 30 and $100 \mathrm{mg} / \mathrm{kg}$, p.o.) or glibenclamide (10 mg/kg, p.o.) had significantly reduced STZ-induced increases in blood glucose (BG), total cholesterol (TC) and serum triglycerides (TGs). Unlike glibenclamide that showed significant reductions in BG, TC and TGs in normoglycemic mice, a, $\beta$-amyrin did not lower normal blood sugar levels but at $100 \mathrm{mg} / \mathrm{kg}$, manifested a hypolipidemic effect. Also, a, $\beta$-amyrin effectively reduced the elevated plasma glucose levels during the oral glucose tolerance test. Moreover, the plasma insulin level and histopathological analysis of pancreas revealed the beneficial effect of $a$, $\beta$-amyrin in the preservation of beta cell integrity. In mice treated orally with a, $\beta$-amyrin $(10,30$ and $100 \mathrm{mg} / \mathrm{kg})$ or fenofibrate (200 mg/kg), the HFD-associated rise in serum TC and TGs were significantly less. The hypocholesterolemic effect of a, $\beta$-amyrin appeared more prominent at $100 \mathrm{mg} / \mathrm{kg}$ with significant decreases in VLDL and LDL cholesterol and an elevation of HDL cholesterol. Besides, the atherogenic index was significantly reduced by $a, \beta$-amyrin.
\end{abstract}

Conclusions: These findings reflect the potential antihyperglycemic and hypolipidemic effects of $a$, $\beta$-amyrin mixture and suggest that it could be a lead compound for drug development effective in diabetes and atherosclerosis.

Keywords: Protium heptaphyllum, a, $\beta$-amyrin, Pentacyclic triterpene, Antihyperglycemic and hypolipidemic effects, Mice

\section{Introduction}

Diabetes mellitus (DM) is a metabolic disorder characterized by hyperglycemia resulting from defects in insulin secretion, insulin action or both. Hyperglycemia and hyperlipidemia, as the most common features of diabetes mellitus, contribute to the development of microvascular and macrovascular complications of diabetes, which account for the morbidity and mortality of diabetes [1].

\footnotetext{
* Correspondence: flavia@ufc.br

'Department of Physiology and Pharmacology, Faculty of Medicine, Federal University of Ceará, Fortaleza, Ceará, Brazil

Full list of author information is available at the end of the article
}

Search for compounds that normalize hyperglycemia, hyperlipidemia and ameliorate oxidative stress is an important objective in preventing diabetes-associated complications. None of the currently used medications reverse ongoing failure of beta cell function [2]. The search for newer drugs from natural sources, which are cost-effective and safe, without the long-term side effects may open new avenues for the treatment of diabetes and diabetes associated complications [3].

In the recent past, many pentacyclic triterpenes were shown to improve lipoprotein lipase expression, insulin sensitivity and dyslipidemia [4-7]. The resin obtained

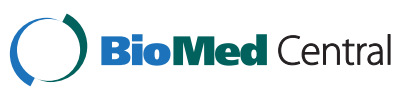


from the trunk wood of Protium heptaphyllum (Aubl.) March (Burseraceae) is a reputed folk medicinal agent because of its analgesic and anti-inflammatory properties [8]. Chemical investigations have revealed the presence of $\alpha, \beta$-amyrin, a pentacyclic triterpene as the major component of resin, and pharmacological studies have revealed anti-inflammatory and antinociceptive, antioxidant, antipruritic, gastroprotective and hepatoprotective effects, at non-toxic doses, which range from 10 to $100 \mathrm{mg} / \mathrm{kg}$ [9-16]. The pentacyclic triterpene $\alpha, \beta-$ amyrin (Figure 1) is constituted of triterpenes, that belongs to the group of ursane and oleanane series and that this class of agents has the chemical structure similar to that of a steroid and are extremely useful in prevention or treatment of many diseases in experimental animals, particularly those in which oxidative and inflammatory stress plays a key role in pathogenesis [17]. Several studies addressed on the molecular mechanism of the anti-inflammatory and antinociceptive actions of $\alpha, \beta$-amyrin, using different experimental models. One study has shown its preventive or therapeutic antiinflammatory potential in a murine model of trinitrobenzene-sulfonic acid (TNBS)-induced colitis, wherein $\alpha$, $\beta$-amyrin was found to be as efficacious as dexamethasone in reversing the macroscopic and microscopic outcomes of TNBS-induced colitis through suppression of inflammatory cytokines and cyclooxygenase-2 levels, and by inhibition of NF-kB activation [11]. In other studies, $\alpha$, $\beta$-amyrin ameliorated periodontal inflammation in rat model of ligature-induced periodontitis reducing the neutrophil infiltration, oxidative stress and the production of proinflammatory cytokine TNF- $\alpha,[10]$ and exhibited long-lasting antinociceptive and anti-inflammatory properties in 2 models of persistent nociception via activation of cannabinoid receptors and by inhibiting the production of cytokines and expression of NF- $\mathrm{kB}$, and cyclooxygenase $2[12,13]$. Because both increased oxidative stress and augmented expression of inflammatory mediators are hallmarks of diabetes [18], and since $\alpha, \beta$ amyrin demonstrates antioxidant and anti-inflammatory properties, we have examined this triterpene for its possible hypoglycemic effect on streptozotocin (STZ)induced diabetic mice and lipid-lowering effect in mice fed on a high-fat diet. Although $\alpha, \beta$-amyrin has previously been evaluated for hypoglycemic activity using the models of STZ-induced diabetic rat and diabetic $\mathrm{db} / \mathrm{db}$ mice [19], to the best of our knowledge there were no such reports on $\alpha, \beta$-amyrin and therefore the present study.

\section{Materials and methods}

\section{Extraction and isolation of $\alpha, \beta$-amyrin}

The resinous exudates from the trunk wood of Protium heptaphyllum (March.) was collected from the municipal areas of Timon, Maranhão state of Brazil, after its identification by botanist Roseli Farias de Melo Barros. A voucher sample (\#18247) has been deposited at the Herbarium Graziela Barroso of the Federal University of Piauí, Teresina, Brazil. The extraction and isolation of $\alpha, \beta$-amyrin from the crude resin was carried out as described earlier [20] and its structural identity was confirmed by ${ }^{1} \mathrm{H}$ - and ${ }^{13} \mathrm{C}-\mathrm{NMR}$ spectral analysis, based on the method developed by Gallegos and Roque [21] and comparison to literature data [22]. The ratio of $\alpha, \beta$-amyrin in this mixture was 63:37.

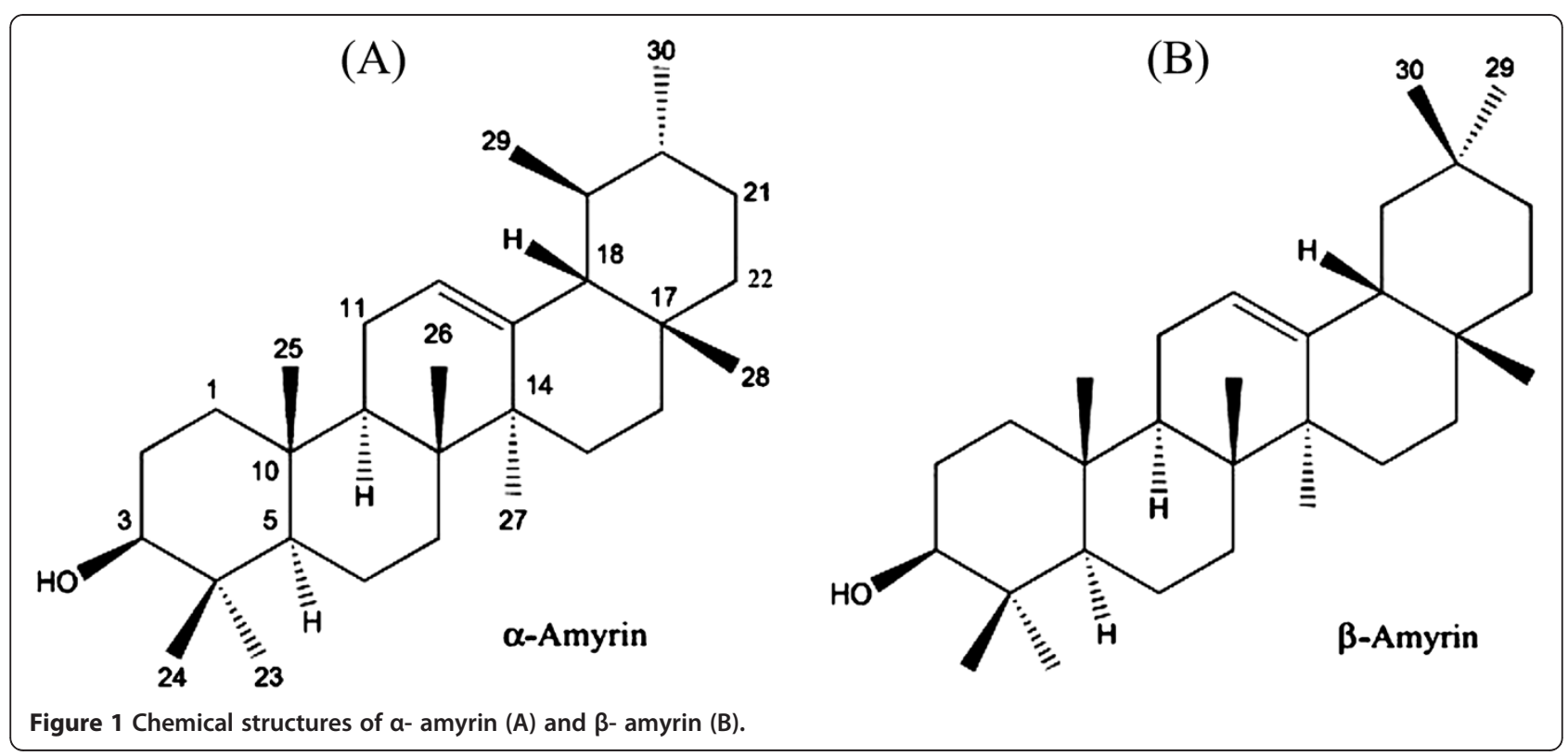




\section{Animals}

Male Swiss mice weighing 25-30 g were maintained at a constant room temperature $\left(22-23^{\circ} \mathrm{C}\right)$ with light-dark cycles of $12 \mathrm{~h}$ and were allowed free access to water and standard laboratory chow. Experimental protocols were approved by the Institutional Committee on Care and Use of Animals for Experimentation (No. 22/09) in accordance with the guidelines of the National Institutes of Health, Bethseda, MD, U.S.A.

\section{Blood glucose and lipids in normal animals}

Animals were divided into groups of 8 mice in each. A group served as normal control mice were treated orally with distilled water $(10 \mathrm{~mL} / \mathrm{kg})$ only. The mice in the other groups received orally the vehicle ( $2 \%$ Tween 80 in distilled water, $10 \mathrm{~mL} / \mathrm{kg}), \alpha, \beta$-amyrin $(10,30$ or $100 \mathrm{mg}$ / $\mathrm{kg}$ ) or glibenclamide $(10 \mathrm{mg} / \mathrm{kg})$, once daily for 5 days. Following a $6 \mathrm{~h}$ fast, and at the end of the treatments on day-5, blood samples were drawn from the tail vein. Blood glucose, total cholesterol and triglycerides levels were determined using a semi-automatic analyser (Labquest, Labtest, Brazil) using diagnostic kits (Labtest, Brazil).

\section{Experimental induction of diabetes}

The hypoglycemic activity of $\alpha, \beta$-amyrin was evaluated in STZ-diabetic mice. Diabetes was induced by intraperitoneal injection of streptozotocin (STZ) $(125 \mathrm{mg} / \mathrm{kg}$ in citrate buffer, $\mathrm{pH}$ 4.5) [23]. After $72 \mathrm{~h}$ of STZ administration, the mice with blood glucose level greater than $200 \mathrm{mg} / \mathrm{dL}$ were separated and divided into 6 groups of eight animals each. Group 1 was the normal control and contained mice treated orally with distilled water while group 2 was vehicle control and contained diabetic mice treated with vehicle (2\% Tween 80 in distilled water, $10 \mathrm{~mL} / \mathrm{kg}$, p.o.). Mice in groups 3 to 6 were diabetic mice that received orally $\alpha, \beta$-amyrin 10,30 and $100 \mathrm{mg} / \mathrm{kg}$ and glibenclamide $10 \mathrm{mg} / \mathrm{kg}$, respectively. Blood samples were collected from the tail vein at $3 \mathrm{~h}$ and $5 \mathrm{~h}$ after the treatments and the blood glucose was analysed by colorimetric method in a semi-automatic analyser (Labquest, Labtest, Brasil) using diagnostic kit (Labtest, Brazil). Plasma insulin levels were measured from $5 \mathrm{~h}$ blood sample using a rat/mouse insulin enzyme-linked immunosorbent assay according to the manufacturer's instructions. The animals were euthanized; pancreas collected, fixed in $10 \%$ formalin, and were then embedded in paraffin to prepare sections using standard protocols. Pancreatic sections were stained with Hematoxylin and Eosin and were examined under light microscopy for morphological analysis.

\section{Oral Glucose Tolerance Test (OGTT)}

Mice were divided into groups of 08 mice each. A group served as normal control mice treated orally with distilled water only. The mice in the other groups received vehicle (2\% Tween in distillated water, $10 \mathrm{~mL} /$ $\mathrm{kg}$, p.o.), $\alpha, \beta$-amyrin (10, 30 or $100 \mathrm{mg} / \mathrm{kg}$, p.o.) or glibenclamide $(10 \mathrm{mg} / \mathrm{kg}$, p.o.). Vehicle, $\alpha, \beta$-amyrin or glibenclamide were administered once daily for five days. On day 5 after a $6 \mathrm{~h}$ starvage, and $2 \mathrm{~h}$ after the respective treatments, blood samples from the tail vein were collected and the blood glucose was determined $(0 \mathrm{~h})$. Groups 2-6 were administered glucose $(2 \mathrm{~g} / \mathrm{kg})$ orally as a bolus. Blood samples of all groups were collected from tail vein at 30, 60 and 90 min time point for measurment of blood glucose.

\section{Hypercholesterolaemia induced by diet}

Albino male mice were divided into groups of eight in each. One group served as normal control and received normal pelleted feed and had free access to drinking water. The mice in the other groups received, in addition to pelleted diet and water, a hyperlipidemic diet witch was a combination of sunflower oil $(10 \mathrm{~mL} / \mathrm{kg}), 5 \%$ cholesterol and $0.5 \%$ cholic acid by oral gavage for two weeks [24]. Vehicle (2\% Tween 80 in distilled water, $10 \mathrm{~mL} / \mathrm{kg}$ ), $\alpha, \beta$-amyrin $(10,30$ or $100 \mathrm{mg} / \mathrm{kg})$ or fenofibrate $(200 \mathrm{mg} / \mathrm{kg}$ ) were administered orally once daily to mice $4 \mathrm{~h}$ after feeding. The body weight of animals was recorded at the end of the second week. At the end of two weeks, following an overnight fast, blood samples from the tail vein were collected and serum total cholesterol (TC), HDL-cholesterol (HDL-c) and triglycerides (TG) were analysed by colorimetric method in a semiautomatic analyzer (Labquest, Labtest, Brazil) using diagnostic kits (Labtest, Brazil). The serum low-density lipoprotein-cholesterol (LDL-c) and very-low-density lipoprotein-cholesterol (VLDL-c) concentrations were calculated using the Friedewald formula [20], where $\mathrm{LDL}-\mathrm{c}=\mathrm{TC}-($ HDL-c + VLDL-c) and VLDL-c $=\mathrm{TG} / 5$. The atherogenic index (AI) was expressed as LDL-C + VLDL-c/HDL-c.

\section{Statistical analysis}

All data are presented as mean \pm SEM. The data were evaluated by one-way analysis of variance with Newman-Keuls posthoc test using the GraphPad Prism 4.0 statistical program. The level of significance was set at $\mathrm{p} \leq 0.05$.

\section{Results}

Table 1 shows that a 5 -day administration of $\alpha, \beta$-amyrin $(10,30$ and $100 \mathrm{mg} / \mathrm{kg})$ in normal mice did not significantly reduce the blood glucose level. However, glibenclamide $(10 \mathrm{mg} / \mathrm{kg})$ caused a significant reduction in blood glucose level when compared to vehicle-treated control group. Treatments with $\alpha, \beta$-amyrin $(100 \mathrm{mg} / \mathrm{kg})$ 
Table 1 Effects of $\alpha, \beta$-amyrin and glibenclamide treatments on blood glucose, total cholesterol and triglycerides in normal mice

\begin{tabular}{|c|c|c|c|c|}
\hline Group & Dose $(\mathrm{mg} / \mathrm{kg})$ & Blood glucose (mg/dL) & Total Cholesterol (mg/dL) & Triglycerides $(\mathrm{mg} / \mathrm{dL})$ \\
\hline Normal Control & - & $114.50 \pm 5.11$ & $93.60 \pm 11.66$ & $143.10 \pm 11.40$ \\
\hline Vehicle Control & - & $115.75 \pm 5.61$ & $96.00 \pm 5.12$ & $151.10 \pm 14.62$ \\
\hline$a, \beta$-amyrin & $10 \mathrm{mg} / \mathrm{kg}$ & $106.83 \pm 1.47$ & $97.63 \pm 10.39$ & $114.60 \pm 8.19$ \\
\hline$a, \beta$-amyrin & $30 \mathrm{mg} / \mathrm{kg}$ & $101.67 \pm 2.55$ & $92.75 \pm 7.74$ & $116.00 \pm 8.01$ \\
\hline$a, \beta$-amyrin & $100 \mathrm{mg} / \mathrm{kg}$ & $100.43 \pm 4.92$ & $72.57 \pm 9.32^{a, b}$ & $97.00 \pm 9.76^{a, b}$ \\
\hline Glibenclamide & $10 \mathrm{mg} / \mathrm{kg}$ & $87.14 \pm 5.21^{a, b}$ & $69.17 \pm 2.18^{a, b}$ & $82.38 \pm 2.66^{a, b}$ \\
\hline
\end{tabular}

Each value represents the mean \pm SEM,$n=8$ mice. ${ }^{a} p<0.05$ compared with normal control. ${ }^{b} p<0.05$ compared with vehicle control.

as well as glibenclamide also showed significantly reduced total cholesterol and triglycerides levels.

Figure 2 shows the effect of $\alpha, \beta$-amyrin and glibenclamide in streptozotocin-diabetic mice. In vehicle control group the blood glucose level was significantly elevated $3 \mathrm{~h}$ and $5 \mathrm{~h}$ after treatment when compared with normal control mice. The triterpenoid (10, 30 and $100 \mathrm{mg} / \mathrm{kg}$ ) and glibenclamide $(10 \mathrm{mg} / \mathrm{kg})$ treatments were able to reduce significantly the STZ-associated increase in blood glucose level at time points of $3 \mathrm{~h}$ and $5 \mathrm{~h}$. Both $\alpha$, $\beta$-amyrin $(100 \mathrm{mg} / \mathrm{kg})$ and glibenclamide $(10 \mathrm{mg} / \mathrm{kg})$ were able to elevate significantly the insulin levels at time $5 \mathrm{~h}$.

Figure 3 depicts the results of histological analysis of pancreas from normal or STZ-diabetic mice treated or not with either $\alpha, \beta$-amyrin or glibenclamide. Figure 3A representing pancreatic section from normal mice that show well defined islets of Langerhans surrounded by

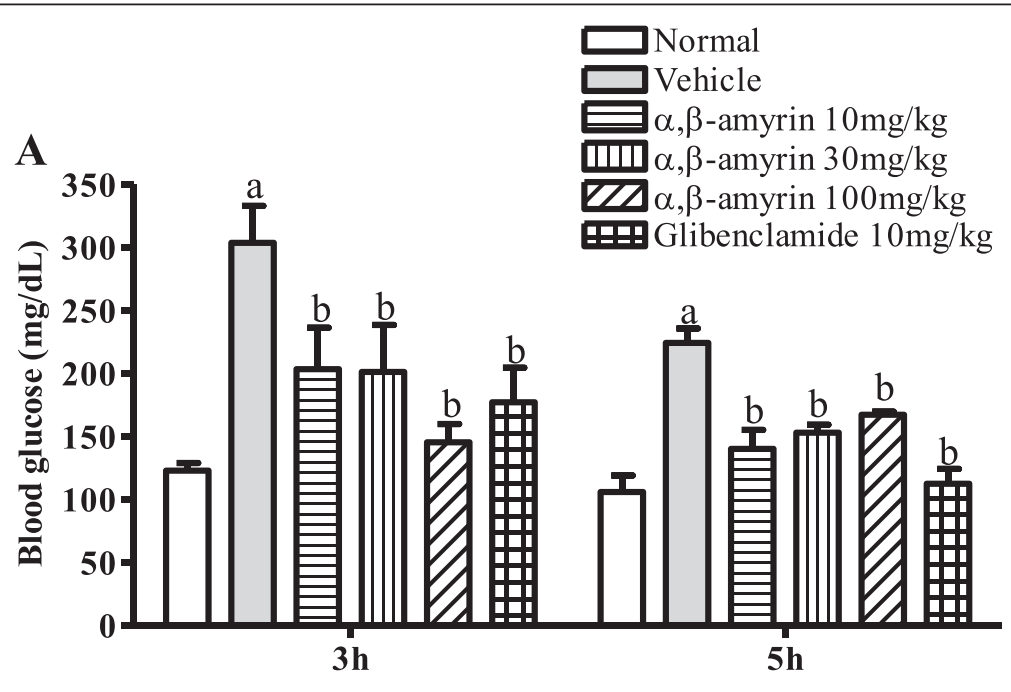

B

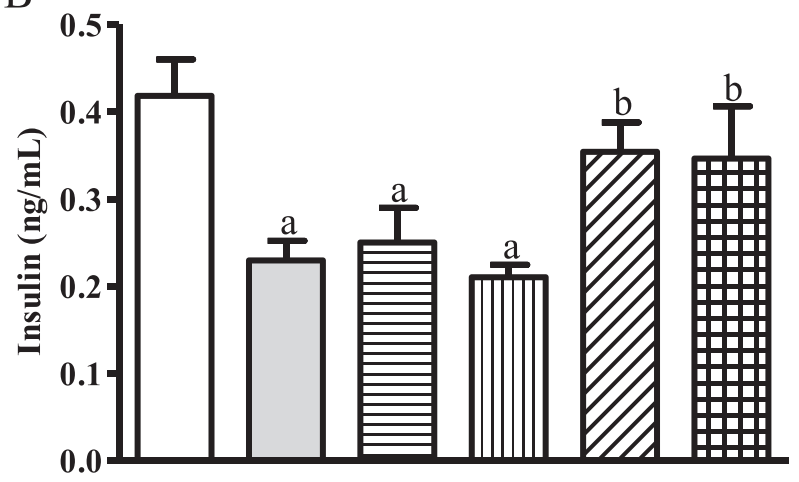

Figure 2 Treatment effects of $\alpha, \beta$-amyrin or glibenclamide on blood glucose levels and insulin levels in streptozotocin (STZ)-induced diabetic mice. Each bar represents the mean \pm SEM $(n=8)$ of blood glucose $(\mathrm{mg} / \mathrm{dL})$ at time $3 \mathrm{~h}$ and $5 \mathrm{~h}(\mathbf{A})$ or insulin at time $5 \mathrm{~h}(\mathbf{B}){ }^{a} \mathrm{p}<0.05$ compared with normal control. ${ }^{b} p<0.05$ compared with vehicle control. 

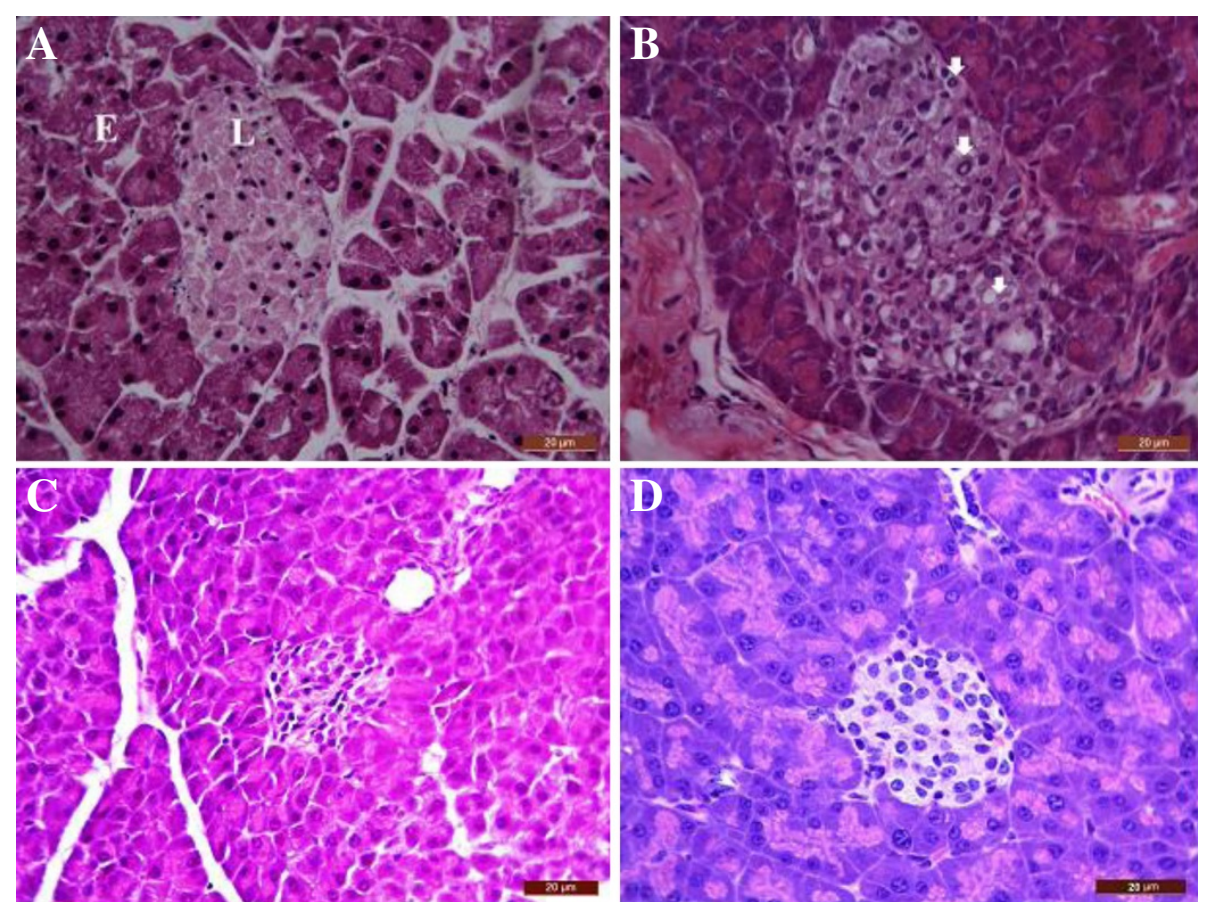

Figure 3 Histology of mouse pancreas stained by Hematoxylin \& Eosin. Normal islets of Langerhans (L) surrounded by exocrine portion (E) of pancreatic tissues in control mice (A). Destruction and distortion of endocrine cells in STZ-diabetic mice with the presence of necrotic cells and inflammatory cells (arrowhead) (B). C: Improvement in morphology of islets of Langerhans with a, $\beta$-amyrin (100 mg/kg) pretreatment in STZ-diabetic mice; $\mathbf{D}$ : Islets of Langerhans of diabetic mice treated with glibenclamide $(10 \mathrm{mg} / \mathrm{kg})$ showing restoration of normal cellular population. (H \& E 400x), Bar: $20 \mu m$.

exocrine portion of pancreatic tissues. Pancreas sections from untreated diabetic mice (Figure 3B) showed both destruction and distortion of endocrine cells. Apart from this, necrotic cells and inflammatory cells were present. The diabetic mice treated with $\alpha, \beta$-amyrin $(100 \mathrm{mg} / \mathrm{kg})$ showed no morphological changes of islets of Langerhans and the features were almost similar to control pancreas (Figure 3C). Histological sections from STZdiabetic mice treated with glibenclamide also showed protection from the destructive effect of STZ, showing normal cellular population (Figure 3D).

Figure 4 depicts the pretreatment effects of $\alpha, \beta$ amyrin $(10,30$ and $100 \mathrm{mg} / \mathrm{kg}$ ) and glibenclamide $(10 \mathrm{mg} / \mathrm{kg})$ on oral glucose tolerance test. Before the glucose load, the basal blood glucose levels were not significantly different between the groups. In this test, while normal control showed no significant changes in the levels of blood glucose, at all time points $(0,30,60$, and $90 \mathrm{~min}$ ) of observation, vehicle-treated mice loaded with oral glucose manifested an increase in blood glucose at the time points of 30, 60 and $90 \mathrm{~min}$. The five-day oral pretreatment with $\alpha, \beta$-amyrin $(10,30$ and $100 \mathrm{mg} / \mathrm{kg}$ ) and glibenclamide significantly improved the glucose tolerance at the 30, 60 and 90 min periods.

The serum lipid profiles of mice after a two weeks normal or high-fat diet are shown in Table 2. The normal group of mice fed on normal chow diet had serum total cholesterol and triglycerides levels of $119.00 \pm 5.86$ and $48.85 \pm 5.94 \mathrm{mg} / \mathrm{dL}$, respectively as against $225.40 \pm 10.93$ and $258.80 \pm 27.48 \mathrm{mg} / \mathrm{dL}$, respectively, in mice on the high-fat diet. Orally administered $\alpha, \beta$-amyrin (10, 30 and $100 \mathrm{mg} / \mathrm{kg}$ ) and fenofibrate $(200 \mathrm{mg} / \mathrm{kg})$ significantly decreased the high-fat-diet-induced increases in total cholesterol and triglycerides. The cholesterol fractions HDL, VLDL and LDL were significantly increased by a high-fat diet. $\alpha, \beta$-amyrin $(10,30$ and $100 \mathrm{mg} / \mathrm{kg}$ ) and

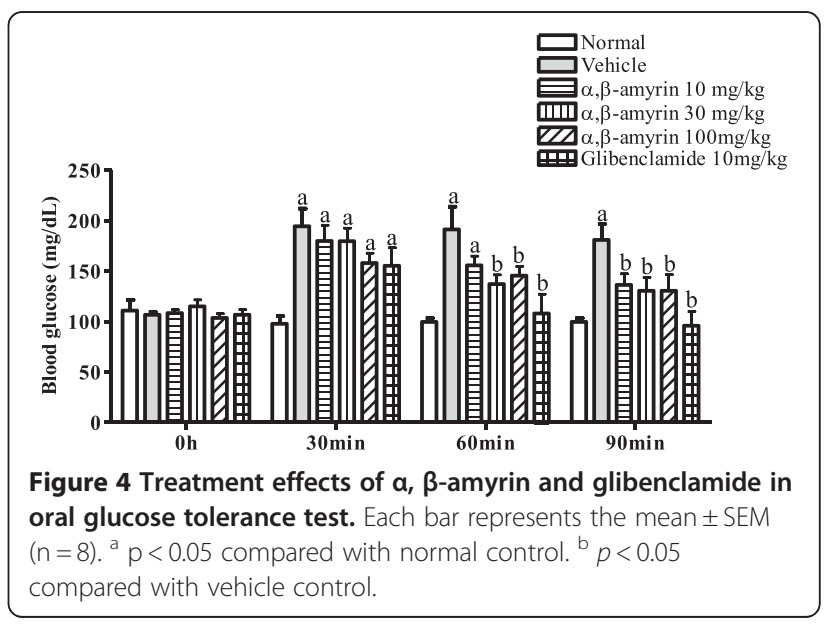


Table 2 Effects of $\alpha, \beta$-amyrin and fenofibrate treatments on serum lipid parameters in mice

\begin{tabular}{|c|c|c|c|c|c|c|}
\hline \multirow[t]{2}{*}{ Lipid parameter } & \multirow{2}{*}{$\begin{array}{l}\text { Normal diet } \\
\text { (control) }\end{array}$} & \multicolumn{5}{|c|}{ High-fat diet and treated } \\
\hline & & $\begin{array}{l}\text { Vehicle } \\
\text { Control } \\
\end{array}$ & $\begin{array}{l}\alpha, \beta \text {-amyrin } \\
10 \mathrm{mg} / \mathrm{kg}\end{array}$ & $\begin{array}{l}\alpha, \beta \text {-amyrin } \\
30 \mathrm{mg} / \mathrm{kg}\end{array}$ & $\begin{array}{l}\text { a, } \beta \text {-amyrin } \\
100 \mathrm{mg} / \mathrm{kg}\end{array}$ & $\begin{array}{l}\text { Fenofibrate } \\
200 \mathrm{mg} / \mathrm{kg}\end{array}$ \\
\hline Total cholesterol (mg/dL) & $119.00 \pm 5.86$ & $225.40 \pm 10.92^{a}$ & $175.90 \pm 9.62^{b}$ & $175.60 \pm 13.32^{b}$ & $166.30 \pm 8.97^{b}$ & $143.40 \pm 7.48^{b}$ \\
\hline Triglycerides (mg/dL) & $48.85 \pm 5.94$ & $258.80 \pm 27.48^{\mathrm{a}}$ & $204.7 \pm 26.01^{b}$ & $146.70 \pm 21.24^{b}$ & $50.50 \pm 6.66^{b}$ & $70.71 \pm 13.48^{b}$ \\
\hline $\mathrm{HDL}-\mathrm{c}(\mathrm{mg} / \mathrm{dL})$ & $26.13 \pm 1.42$ & $39.00 \pm 1.59^{\mathrm{a}}$ & $48.63 \pm 4.78$ & $63.38 \pm 7.12^{b}$ & $71.25 \pm 3.21^{b}$ & $71.14 \pm 3.92^{b}$ \\
\hline VLDL-c (mg/dL) & $9.75 \pm 1.18$ & $48.91 \pm 5.45^{\mathrm{a}}$ & $40.94 \pm 5.20$ & $33.65 \pm 4.21^{\mathrm{b}}$ & $10.10 \pm 1.33^{b}$ & $14.14 \pm 2.69^{b}$ \\
\hline LDL-c (mg/dL) & $83.29 \pm 7.07$ & $137.20 \pm 12.32^{a}$ & $81.38 \pm 16.00^{b}$ & $100.10 \pm 12.88^{b}$ & $90.65 \pm 11.22^{b}$ & $58.14 \pm 8.62^{b}$ \\
\hline Atherogenic index (Al) & $3.65 \pm 0.32$ & $4.78 \pm 0.34^{\mathrm{a}}$ & $3.01 \pm 0.45^{b}$ & $2.23 \pm 0.49^{b}$ & $1.46 \pm 0.22^{b}$ & $1.09 \pm 0.21^{b}$ \\
\hline
\end{tabular}

Each value represents the mean \pm S.E.M. $(n=8) .{ }^{a} p<0.05$ compared with normal diet-fed control. ${ }^{b} p<0.05$ compared with vehicle control.

fenofibrate $(200 \mathrm{mg} / \mathrm{kg})$ significantly reduced the LDL levels and only $\alpha, \beta$-amyrin at doses of 30 and $100 \mathrm{mg} /$ $\mathrm{kg}$ reduced the VLDL levels. $\alpha, \beta$-amyrin (30 and $100 \mathrm{mg} / \mathrm{kg}$ ) and fenofibrate significantly increased the HDL levels. $\alpha, \beta$-amyrin $(10,30$ and $100 \mathrm{mg} / \mathrm{kg})$ and fenofibrate significantly lowered the atherogenic index. At the end of two weeks, significant differences were observed in the final body weights between the normal diet control group $(30.63 \pm 1.62 \mathrm{~g})$ and the high-fat diet control $(37.75 \pm 0.56 \mathrm{~g})$ mice. When compared to vehicle-treated high-fat diet mice, the observed final body weights were significantly lower in animal groups that received $\alpha, \beta$-amyrin 10,30 and $100 \mathrm{mg} / \mathrm{kg}$ $(32.25 \pm 1.72 ; 32.25 \pm 0.75$ and $30.63 \pm 0.94$ g, respectively) and fenofibrate $200 \mathrm{mg} / \mathrm{kg}(31.14 \pm 1.78 \mathrm{~g})$.

\section{Discussion}

The results of this study clearly demonstrates that the pentacyclic triterpene $\alpha, \beta$-amyrin isolated from Protium heptaphyllum exerts antihyperglycemic and hypolipidemic effects in mouse models of STZ-induced diabetes and high-fat diet-induced hyperlipidemia, highly relevant to experimental diabetes research [25-27]. These results are consistent with our previous reports that show similar effects with other pentacyclic triterpenes like betulinic, oleonolic, and ursolic acids in yet another mouse model of high-fat fed-induced obesity [28-30]. Excessive production of nitric oxide and the subsequent increase in local oxidative stress, or altered intracellular $\mathrm{Ca}^{+2}$ regulation, are some suggested pathogenic mechanisms in pancreatic beta-cell death and the development of insulin-dependent diabetes mellitus-induced by STZ [31]. Many conventional drugs used to treat diabetes act by improving insulin sensitivity, increasing insulin production, and or by decreasing the level of blood glucose. Decrease in blood glucose might be a consequence of reduced glucose absorption from gut, inhibition of glucose production in hepatic tissue, and or increased uptake by muscle and adipose tissue. The results of the OGTT further support these findings.
The molecular mechanism(s) by which $\alpha, \beta$-amyrin manifests antihyperglycemic and antilipidemic effect are not clear. A recent study has largely explored the molecular mechanisms through which $\alpha, \beta$-amyrin exerts its anti-inflammatory and anitinoceptive actions, including the first demonstration that this pentacyclic triterpene interacts with cannabinoid system [12]. An yet another study reported that $\alpha, \beta$-amyrin has an inhibitory effect on 2-arachidonoylglycerol (2-AG) hydrolysis, and consequently increases the endocannabinoids [13]. Animal studies clarified the important role of endocannabinoid system and the cannabinoid 1 (CB1) receptors in the hypothalamus and in the limbic system in mediating orexigenic effects [32]. Recent studies indicate that some CB1 ligands may directly bind and allosterically regulate Kir6.2/SUR1 K(ATP) channels like other potassium channel openers (KCOs) and thus cause body weight-independent improvements in insulinemia and glycemia [33,34]. We hypothesise that $\alpha, \beta$-amyrin improves glycemia possibly by its interaction with cannabinoid system and warrants a future investigation.

Triterpenoids in general have poor bioavailability and so is the case with $\alpha, \beta$-amyrin. Pharmacokinetic investigations with a reliable GC-MS method reveal that amyrin has low bioavailabilty but a long elimination half life, following its oral administration to normal rats [35]. However, earlier works [9-16] show that it is orally effective in several animal models of inflammation, nociception, gastroprotection and hepatoprotection. Also, the present study demonstrates the oral efficacy of alpha, betaamyrin in reducing hyperglycemia and hyperlipidemia in the experimental models of STZ-induced diabetes and diet induced hyperlipidemia.

A pathogenic role for tumor necrosis factor-alpha (TNF- $\alpha$ ) in mice with Type 1- and 2- diabetes and the efficacy of anti- TNF- $\alpha$ treatment in ameliorating hyperglycemia and restoring normal insulin has been recently addressed [36]. In a previous study, we demonstrated the anti-inflammatory and antioxidant effects of $\alpha, \beta$-Amyrin in rodent models of ceruleininduced acute pancreatitis and ligature-induced acute 
periodontitis $[9,10]$, wherein this triterpenoid was found to significantly inhibit the serum level of proinflammatory cytokine TNF- $\alpha$ as well as the increases in myeloperoxidase (MPO) activity and and thiobarbituric acid-reactive substances (TBARS). In the present study, treatment with $\alpha, \beta$-amyrin effectively restored the reduced insulin levels seen in streptozotocindiabetic controls. These observations strongly suggest that $\alpha, \beta$-amyrin by its anti-inflammatory and antioxidative effects, may be in part, exercise beneficial effects in diabetic rats.

It is known that glibenclamide binds to $\mathrm{K}_{\mathrm{ATP}}+$ channel on the cell membrane of pancreatic beta cells thereby blocking out flux of potassium ions and opening voltage gated $\mathrm{Ca}_{2}+$ channels. This rise in intracellular calcium promoted by glibenclamide eventually leads to increased secretion of insulin [37]. Glibenclamide used as a positive control in the study is a sulfonylurea derivative clinically used for treating hyperglycemia but has been associated with severe and sometimes fatal hypoglycemia [38]. Unlike sulphonylurea compound glibenclamide, oral administration of $\alpha, \beta$-amyrin failed to produce hypoglycemia in normal animals. This suggests that the mode of action of the plant terpenoid is probably mediated by other mechanism(s). Literature reports suggest that many plant-derived triterpenoids might enhance glucose uptake by acting as insulin mimics and as insulin sensitizers [39], some exhibit alpha-glucosidase inhibition [40]. Insulin resistance affects not only the regulation of carbohydrate metabolism but all aspects of lipid and lipoprotein metabolism and is associated with elevated VLDL and increased triglycerides [41]. Therefore the observed diminution of VLDL and the hypertriglyceridemia by $\alpha, \beta$-amyrin might be a result of improved insulin sensitivity.

In summary, we have demonstrated that $\alpha, \beta$-amyrin, a pentacyclic triterpene ameliorates hyperglycemia and dyslipidemia, reduces atherogenic risk factor, and improves glucose tolerance in mice possibly by its anti-inflammatory and antioxidant effects. However, the molecular mechanism(s) underlying these effects of $\alpha, \beta$-amyrin remains to be established.

\footnotetext{
Abbreviations

Al: Atherogenic index; 2-AG: 2-arachidonoylglycerol; BG: Blood glucose; CB1: Cannabinoid 1; DM: Diabetes mellitus; HDL-c: High density lipoproteincholesterol; KCOs: Potassium channel openers; LDL-c: Low density lipoprotein-cholesterol; MPO: Myeloperoxidase; OGTT: Oral glucose tolerance test; STZ: Streptozotocin; TBARS: Thiobarbituric acid-reactive substances; TC: Total cholesterol; TG: Triglycerides; TNF-a: tumor necrosis factor-alpha; VLDL-c: Very low density lipoprotein-cholesterol.
}

\section{Competing interests}

The authors declare that they have no competing interests.

\section{Author's contributions}

JTF, TSM, BRA, NTPC performed animal experiments and statistical analysis, and contributed to writing of the manuscript; MHC, AACAS contributed to isolation and chemical identification of a, $\beta$-amyrin; GACB performed the histological analysis; VSR and FAS participated in the design and coordination of the study and contributed to writing of the manuscript. All authors read and approved the final version of the manuscript.

\section{Acknowledgements}

The present study was funded by National Counsel of Technological and Scientific Development (CNPq) and Foundation for the Support of Scientific and Technological Development of the Ceará State (FUNCAP).

\section{Author details}

${ }^{1}$ Department of Physiology and Pharmacology, Faculty of Medicine, Federal University of Ceará, Fortaleza, Ceará, Brazil. ${ }^{2}$ Department of Clinical and Toxicological Analysis, Faculty of Pharmacy, Odontology and Nurse, Federal University of Ceará, Fortaleza, Ceará, Brazil. "3Department of Chemistry, Federal University of Piauí, Teresina, Piauí, Brazil. ${ }^{4}$ Department of Morphology, Faculty of Medicine, Federal University of Ceará, Fortaleza, Ceará, Brazil.

Received: 23 November 2011 Accepted: 24 July 2012

Published: 6 August 2012

\section{References}

1. Taskinen MR: Diabetic dyslipidemia. Atheroscler Supp/ 2002, 3:47-51.

2. Hao E, Tyrberg B, Itkin-Ansari P, Lakey JR, Geron I, Monosov EZ, Barcova M, Mercola M, Levine F: Beta-cell differentiation from nonendocrine epithelial cells of the adult human pancreas. Nat Med 2006, 12:310-316.

3. Schlyer S, Horuk R: I want a new drug: G-protein-coupled receptors in drug development. Drug Discov Today 2006, 11:481-493.

4. Gao D, Li Q, Li Y, Liu Z, Fan Y, Liu Z, Zhao H, Li J, Han Z: Antidiabetic and antioxidant effects of oleanolic acid from Ligustrum lucidum Ait in alloxan-induced diabetic rats. Phytother Res 2009, 23:1257-1262.

5. Eu CH, Lim WY, Ton SH, bin Abdul Kadir K: Glycyrrhizic acid improved lipoprotein lipase expression, insulin sensitivity, serum lipid and lipid deposition in high-fat diet-induced obese rats. Lipids Health Dis 2010, 9:81-90.

6. Takagi S, Miura T, Ishihara E, Ishida T, Chinzei Y: Effect of corosolic acid on dietary hypercholesterolemia and hepatic steatosis in KK-Ay diabetic mice. Biomedical Research 2010, 31:213-218.

7. Sheng $\mathrm{H}$, Sun $\mathrm{H}$ : Synthesis, biology and clinical significance of pentacyclic triterpenes: a multi-target approach to prevention and treatment of metabolic and vascular diseases. Nat Prod Rep 2011, 28:543-593.

8. Matos FJA: O Formulário fitoterápico do Professor Dias Rocha: informações sobre o emprego da medicina caseira, de plantas do Nordeste, especialmente do Ceará. Fortaleza: Imprensa Universitária; 1997.

9. Melo CM, Morais TC, Tomé AR, Brito GA, Chaves MH, Rao VS, Santos FA: Anti-inflammatory effect of $a, \beta$-amyrin, a triterpene from Protium heptaphyllum, on cerulein-induced acute pancreatitis in mice. Inflamm Res 2011, 60:673-681.

10. Holanda Pinto SA, Pinto LM, Cunha GM, Chaves MH, Santos FA, Rao VS: Anti-inflammatory effect of alpha, beta-amyrin, a pentacyclic triterpene from Protium heptaphyllum in rat model of acute periodontitis. Inflammopharmacology 2008, 16:48-52.

11. Vitor CE, Figueiredo CP, Hara DB, Bento AF, Mazzuco TL, Calixto JB: Therapeutic action and underlying mechanisms of a combination of two pentacyclic triterpenes, alpha- and beta-amyrin, in a mouse model of colitis. Br J Pharmacol 2009, 157:1034-1044.

12. da Silva KA, Paszcuk AF, Passos GF, Silva ES, Bento AF, Meotti FC, Calixto JB: Activation of cannabinoid receptors by the pentacyclic triterpene $a$, $\beta$-amyrin inhibits inflammatory and neuropathic persistent pain in mice. Pain 2011, 152:1872-1887.

13. Chicca A, Marazzi J, Gertsch J: The antinociceptive triterpene $\beta$-amyrin inhibits 2-arachidonoylglycerol (2-AG) hydrolysis without directly targeting CB receptors. Br J Pharmacol 2012, doi:10.1111/j.14765381.2012.02059.x. in press.

14. Oliveira FA, Lima-Junior RC, Cordeiro WM, Vieira-Júnior GM, Chaves $M H$, Almeida FR, Silva RM, Santos FA, Rao VS: Pentacyclic triterpenoids, alpha, beta-amyrins, suppress the scratching behavior in a mouse model of pruritus. Pharmacol Biochem Behav 2004, 78:719-725.

15. Oliveira FA, Vieira-Júnior GM, Chaves MH, Almeida FR, Santos KA, Martins FS, Silva RM, Santos FA, Rao VS: Gastroprotective effect of the mixture of 
alpha- and beta-amyrin from Protium heptaphyllum: role of capsaicin-sensitive primary afferent neurons. Planta Med 2004, 70:780-782.

16. Oliveira FA, Chaves MH, Almeida FR, Lima RC Jr, Silva RM, Maia JL, Brito GA, Santos FA, Rao VS: Protective effect of alpha- and beta-amyrin, a triterpene mixture from Protium heptaphyllum (Aubl.) March. trunk wood resin, against acetaminophen-induced liver injury in mice. J Ethnopharmacol 2005, 98:103-108.

17. Sporn MB, Liby KT, Yore MM, Fu L, Lopchuk JM, Gribble GW: New synthetic triterpenoids: potent agents for prevention and treatment of tissue injury caused by inflammatory and oxidative stress. J Nat Prod 2011 74:537-45.

18. Zhang L, Zalewski A, Liu Y, Mazurek T, Cowan S, Martin JL, Hofmann SM, Vlassara H, Shi Y: Diabetes-Induced Oxidative Stress and Low-Grade Inflammation in Porcine Coronary Arteries. Circulation 2003, 108:472-478.

19. Singh AB, Yadav DK, Maurya R, Srivastava AK: Antihyperglycaemic activity of alpha-amyrin acetate in rats and db/db mice. Nat Prod Res 2009, 23:876-882.

20. Vieira-Junior GM, Souza CML, Chaves MH: Resina de Protium heptaphyllum: isolamento, caracterização estrutural e avaliação das propriedades térmicas. Química Nova 2005, 28:183-187.

21. Gallegos RS, Roque NE: Análise de misturas de triterpenos por ${ }^{13} \mathrm{C}$ NMR. Química Nova 1990, 13:278-281.

22. Mahato SB, Sen S: Advances in triterpenoid research, 1990-1994. Phytochemistry 1997, 44:1165-1236.

23. Nangle $M R$, Cotter MA, Cameron NE: Protein kinase $C$ beta inhibition and aorta and corpus cavernosum function in streptozotocin-diabetic mice. Eur J pharmacol 2003, 475:99-106.

24. Arichi H, Kimura Y, Okuda H, Baba K, Kozawa M, Arichi S: Effects of stilbene components of the roots of Polygonum cuspidatum Sieb. et Zucc. on lipid metabolism. Chem Pharm Bull 1982, 30:1766-1770.

25. Friedewald WT, Levy RI, Fredrickson DS: Estimation of the Concentration of Low-Density Lipoprotein Cholesterol in Plasma, Without Use of the Preparative Ultracentrifuge. Clinical Chemistry 1972, 18:499-502.

26. Rakieten N, Rakieten ML, Nadkarni MV: Studies on the diabetogenic action of streptozotocin (NSC-37917). Cancer Chemother Rep 1963, 29:91-98.

27. Bansal P, Paul P, Mudgal J, Nayak PG, Thomas Pannakal S, Priyadarsini KI, Unnikrishnan MK: Antidiabetic, antihyperlipidemic and antioxidant effects of the flavonoid rich fraction of Pilea microphylla (L.) in high fat diet/streptozotocin-induced diabetes in mice. Exp Toxicol Pathol 2011, doi:10.1016/j.etp.2010.12.009. in press.

28. de Melo CL, Queiroz MG, Arruda Filho AC, Rodrigues AM, de Sousa DF Almeida JG, Pessoa OD, Silveira ER, Menezes DB, Melo TS, Santos FA, Rao VS: Betulinic acid, a natural pentacyclic triterpenoid, prevents abdominal fat accumulation in mice fed a high-fat diet. J Agric Food Chem 2009, 57:8776-8781

29. de Melo CL, Queiroz MG, Fonseca SG, Bizerra AM, Lemos TL, Melo TS, Santos FA, Rao VS: Oleanolic acid, a natural triterpenoid improves blood glucose tolerance in normal mice and ameliorates visceral obesity in mice fed a high-fat diet. Chem Biol Interact 2010, 185:59-65.

30. Rao VS, Melo CL, Queiroz MG, Lemos TL, Menezes DB, Melo TS, Santos FA Ursolic acid, A pentacyclic triterpene from Sambucus australis, prevents abdominal adiposity in mice fed a high-fat diet. J Med Food 2001 14:1375-1382

31. Koo KB, Suh HJ, Ra KS, Choi JW: Protective effect of cyclo (his-pro) on streptozotocin-induced cytotoxicity and apoptosis in vitro. J Microbiol Biotechnol 2011, 21:218-227.

32. Engeli S: Central and peripheral cannabinoid receptors as therapeutic targets in the control of food intake and body weight. Handb Exp Pharmacol 2012, 209:357-381.

33. Bajzer M, Olivieri M, Haas MK, Pfluger PT, Magrisso IJ, Foster MT, Tschöp MH, Krawczewski-Carhuatanta KA, Cota D, Obici S: Cannabinoid receptor 1 (CB1) antagonism enhances glucose utilisation and activates brown adipose tissue in diet-induced obese mice. Diabetologia 2011 54:3121-3131.

34. Lynch CJ, Zhou Q, Shyng SL, Heal-DJ-Cheetham SC, Dickinson K, Gregory P, Firnges M, Nordheim U, Goshorn S, Reiche D, Turski L, Antel J: Some cannabinoid receptor ligands and their distomers are direct-acting openers of SUR1 K(ATP) channels. Am J Physiol Endocrinol Metab 2012, 302:E540-E551.
35. Ching J, Lin HS, Tan CH, Koh HL: Quantification of $\alpha$ - and $\beta$-amyrin in rat plasma by gas chromatography-mass spectrometry: application to preclinical pharmacokinetic study. J Mass Spectrom 2011, 46:457-64.

36. Koulmanda M, Bhasin M, Awdeh Z, Qipo A, Fan Z, Hanidziar D, Putheti P, Shi H, Csizuadia E, Libermann TA, Strom TB: The Role of TNF-a in Mice with Type 1- and 2- Diabetes. PLoS One 2012, 7:e33254.

37. Mukai J, Tada H, Watanabe Y, Miura M, Katsuyama S, Shoji T, Mouri K, Eto M, Suzuki T: Lipids behavior and adverse effects for oral antidiabetic agents in patients with Type 2 diabetes treated with sulfonylureas alone based on systematic review. Yakugaku Zasshi 2007, 127:1747-1756.

38. Davis SN, Granner DK, Hardman JG, Limbird LE: Insulin, oral hypoglycemic agents, and the pharmacotherapy of the endocrine pancreas. In Goodman \& Gilman's The pharmacological basis of therapeutics. 11th edition. New York: McGraw-Hill Co; 1996:1487-1517.

39. Ms L, Thoung PT: Stimulation of glucose uptake by triterpenoids from Weigela subsessilis. Phytother Res 2010, 24:49-53.

40. Kang W, Zhang L, Song Y: Alpha-glucosidase inhibitors from Luculia pinciana. Zhongguo Zhong Yao Za Zhi 2009, 34:406-409.

41. Choi SH, Ginsberg HN: Increased very low density lipoprotein (VLDL) secretion, hepatic steatosis, and insulin resistance. Trends Endocrinol Metab 2011, 22:353-363.

\section{doi:10.1186/1476-511X-11-98}

Cite this article as: Santos et al.: Antihyperglycemic and hypolipidemic effects of $a, \beta$-amyrin, a triterpenoid mixture from Protium heptaphyllum in mice. Lipids in Health and Disease 2012 11:98.

\section{Submit your next manuscript to BioMed Central and take full advantage of:}

- Convenient online submission

- Thorough peer review

- No space constraints or color figure charges

- Immediate publication on acceptance

- Inclusion in PubMed, CAS, Scopus and Google Scholar

- Research which is freely available for redistribution 